\title{
Abundance, vertical distribution, and community structure of benthic prokaryotes from permanently cold marine sediments (Svalbard, Arctic Ocean)
}

\author{
Kerstin Sahm ${ }^{1}$, Ulrike-G. Berninger ${ }^{2, *}$ \\ ${ }^{1}$ Molecular Ecology Group and ${ }^{2}$ Microsensor Research Group, \\ Max-Planck Institute for Marine Microbiology, Celsiusstr. 1, D-28359 Bremen, Germany
}

\begin{abstract}
A detailed investigation of the benthic prokaryotic community from 3 permanently cold stations near Svalbard (Arctic Ocean) and 1 site near Tromse (northern Norway) was conducted. Prokaryotic abundances, determined by DAPI-staining, were in the range of ca $2 \times 10^{8}$ to $4 \times 10^{9} \mathrm{cells}^{-3} \mathrm{~cm}^{-3}$ wet sediment. They showed little variation among sampling stations. Vertical profiles were characterized by a decrease of cell numbers with increasing sediment depth. The prokaryotic community composition was investigated employing rRNA (ribosomal RNA) slot-blot hybridization with domain-specific probes. Irrespective of station and vertical depth, Eubacteria always dominated the population, and the relative contribution of Archaea never exceeded $4 \%$. The measured total rRNA concentration and the prokaryotic cell counts in each sample were used to calculate per cell rRNA contents. Mean rRNA content (averaging all samples) was close to $3 \mathrm{fg}$ rRNA cell ${ }^{-1}$. None of our data showed considerable differences to comparable results from temperate or warm habitats; therefore our findings do not allow conclusions on special adaptations of the prokaryotic community to their existence in permanently cold systems. In all samples, but most pronounced in the 3 coldest stations, per cell rRNA contents showed steep vertical gradients with maximum values at the sediment surface. Taking into account all stations, rRNA concentration and prokaryotic abundance were strongly positively correlated below ca $5.5 \mathrm{~cm}\left(\mathrm{r}^{2}=0.739\right)$, whereas in the upper sediment layers $(0$ to $\mathrm{ca} 5.5 \mathrm{~cm}$ ) there was no significant correlation between these 2 parameters. This implies that there may be different mechanisms involved in the control of prokaryotic rRNA contents in different sediment horizons. Cellular rRNA concentrations can give an indication of growth rate and thereby the activity of prokaryotes. This is supported by the fact that we recorded the highest per cell rRNA contents in those stations and sediment depths where other studies conducted simultaneously with our investigation demonstrated the highest rates of metabolic processes.
\end{abstract}

KEY WORDS: Arctic Ocean · Marine sediments - Benthic prokaryotes $\cdot r R N A \cdot$ Prokaryotic activity Archaea

\section{INTRODUCTION}

Temperatures of $5^{\circ} \mathrm{C}$ and less prevail in the world's ocean. More than $90 \%$ of the water column and most of the seafloor are permanently below $5^{\circ} \mathrm{C}$ (Morita 1975, Russel 1990). While in temperate environments prokaryotic activity usually shows a temperature dependence, with low rates during cold seasons (for

\footnotetext{
- Addressee for correspondence. Present address: Institut für Meereskunde, Abteilung Meeresbotanik, Düsternbrooker Weg 20, D-24105 Kiel, Germany.

E-mail: uberninger@ifm.uni-kiel.de
}

review see Rivkin et al. 1996), the effect of temperature on growth and activity of prokaryotes in permanently cold environments is unclear. To date, numerous data sets for prokaryotic abundances in a wide range of water bodies are available (Caron et al. 1982, Albright \& McCrae 1987, Cole et al. 1988, Lochte \& Turley 1988 , Berninger et al. 1991, Sanders et al. 1992, Parkes et al. 1994), and, after reviewing 66 studies on the relationship between temperature and bacterial growth rates from pelagic environments, Rivkin et al. (1996) concluded that '...growth rates of bacterioplankton from cold and temperate oceans are similar at their respective ambient temperatures...'. This clearly indicates an 
adaptation of the pelagic prokaryotic community to permanently low temperatures. In contrast, much less is known about the benthic microbial population in cold environments (Lochte 1992, Boetius \& Lochte 1996). Kröncke et al. (1994) investigated prokaryotic abundances through vertical profiles in the top $6 \mathrm{~cm}$ of sediments along a transect across the Arctic Ocean, looking at differences between shelf environments and deep sea sediments. In their study, prokaryotic numbers were comparable to, albeit on the lower end of, those found in warm or temperate sediments (van Duyl et al. 1993, Starink 1995).

A complex community of prokaryotes is responsible for organic matter degradation in marine sediments (Meyer-Reil \& Köster 1992, Fenchel \& Finlay 1995). However, not much is known yet about the quantitative and qualitative composition of benthic prokaryotic communities and how it varies with latitude. New molecular techniques based on hybridization of oligonucleotide probes to ribosomal RNA (rRNA) enable us to differentiate the 2 prokaryotic domains (Eubacteria and Archaea) and to determine their abundance on a domain, group, or species level independent of cultivation. This method has been shown to be generally applicable for direct measurements in natural habitats (Stahl et al. 1988, Amann et al. 1995, Devereux et al. 1996, Teske et al. 1996, MacGregor et al. 1997 among others). DeLong et al. (1994) showed recently that Archaea are present in high abundances in marine bacterioplankton communities, in particular in antarctic waters. This suggests that Archaea may also be of great importance in cold sediments

IRNA content of bacteria has been shown to be related to their growth rate (Schaechter et al. 1958). Therefore, direct quantification of specific rRNA populations could serve as an indicator of the activity status of a particular community. This is a promising tool, because well-established techniques for the measurement of bacterioplankton growth rates and productivity, e.g. incorporation of radioactively labeled thymidine or leucine, all have some limitations in anoxic sediments (Wellsbury et al. 1996), mainly because they rely on the uptake of a specific substrate. In particular, Wellsbury et al. (1993) showed that pure cultures of different sulfate reducers and methanogens were unable to incorporate thymidine and would therefore not be accounted for when prokaryotic growth rates were determined with $\left[{ }^{3} \mathrm{H}\right]$-thymidine. Since anaerobic processes, mainly sulfate reduction, can account for over $50 \%$ of total carbon mineralization in marine sediments (Jørgensen 1982), the necessity of taking the anaerobic prokaryotic population into account when investigating marine sediments is obvious.

Based on this apparent lack of knowledge of microbial communities from permanently cold marine sedi- ments, the main aim of our study was to quantify benthic prokaryotes from the Arctic Ocean and, by using domain-specific oligonucleotide probes, to establish the relative abundance of Archaea in these systems. For our investigation we used a novel approach combining 'conventional' and molecular techniques in order to overcome the above-mentioned methodological limitations. We present here preliminary evidence that calculated rRNA content per prokaryotic cell may correlate to activity measurements for specific sampling stations and that it might indicate changing zones of microbial activity and interaction along the vertical depth profile of sediments. In order to obtain an even broader understanding of temperature effects it would be desirable to use our approach on permanently warm habitats in the future.

\section{MATERIAL AND METHODS}

Study sites and sampling procedure. Our study was conducted as part of a research cruise in the Arctic Sea from Tromsø (northern Norway) to Svalbard (Spitsbergen) in September/October 1995. Sediments from 4 different stations (I: Malangenfjord; II: Hornsund; III: Van Mijenfjord and V: Storfjord; Table 1) were investigated. Sediment samples were collected with a multicorer. At each site, 2 subcores with an inner diameter of $48 \mathrm{~mm}$ were taken. The individual subcores (our replicates A and B) derived from 2 different multicorer cores. The sediments were anoxic below a depth of ca $8 \mathrm{~mm}$ (B. B. Jørgensen pers. comm.). The overlying water was siphoned off without disturbing the sediment surface and 5 distinct vertical horizons of 2 to $3 \mathrm{~cm}$ thickness were sectioned from the upper $30 \mathrm{~cm}$ of each core (Table 1). The absolute thickness of the individual sediment horizons varied slightly among stations. For easier comparability, an average mean depth of 'ca $5.5 \mathrm{~cm}$ ' refers to the lower border of the top 2 sediment horizons for all stations. The sediment of each section was carefully mixed and subsamples of 1 or $2 \mathrm{~cm}^{3}$ volume were preserved for further analyses.

Total prokaryotic cell counts. Triplicate subsamples for the enumeration of total prokaryotic abundance in each sediment section were fixed with $4 \%$ (final concentration) glutaraldehyde and kept refrigerated $\left(4^{\circ} \mathrm{C}\right)$. For the preparation of microscopic counts small volumes were taken from the well-shaken fixed samples. Sonication of these fixed subsamples in order to separate attached bacteria from sediment particles or to break up bacterial clumps as suggested by Epstein \& Rossel (1995) proved to be counterproductive in our system. The sediment was so fine that sonication resulted in a pulverization of the sediment particles 
Table 1. List of stations and sample distribution

\begin{tabular}{|c|c|c|c|c|c|c|}
\hline Stn no. & Station name & Lat, long. & $\begin{array}{l}\text { Water depth } \\
(\mathrm{m})\end{array}$ & $\begin{array}{l}\text { Bottom water } \\
\text { temperature }\left({ }^{\circ} \mathrm{C}\right)\end{array}$ & $\begin{array}{c}\text { Depth interval of } \\
\text { sediment section }(\mathrm{cm})\end{array}$ & $\begin{array}{l}\text { Mean depth of vertical } \\
\text { sediment sections }(\mathrm{cm})\end{array}$ \\
\hline I & $\begin{array}{l}\text { Malangenfjord } \\
\text { (Tromsø) }\end{array}$ & $\begin{array}{l}69^{\circ} 29.4^{\prime} \mathrm{N} \\
18^{\circ} 07.5^{\prime} \mathrm{E}\end{array}$ & 329 & 7.0 & $\begin{array}{c}0-2 \\
5-8 \\
10-13 \\
15-18 \\
20-23\end{array}$ & $\begin{array}{r}1.0 \\
6.5 \\
11.5 \\
16.5 \\
21.5\end{array}$ \\
\hline II & $\begin{array}{l}\text { Hornsund } \\
\text { (Svalbard) }\end{array}$ & $\begin{array}{l}76^{\circ} 58.2^{\prime} \mathrm{N} \\
15^{\circ} 34.5^{\prime} \mathrm{E}\end{array}$ & 155 & 2.6 & $\begin{array}{c}0-2 \\
3-6 \\
8-11 \\
15-18 \\
25-28\end{array}$ & $\begin{array}{r}1.0 \\
4.5 \\
9.5 \\
16.5 \\
26.5\end{array}$ \\
\hline III & $\begin{array}{l}\text { Van Mijenfjord } \\
\text { (Svalbard) }\end{array}$ & $\begin{array}{l}77^{\circ} 45.7^{\prime} \mathrm{N} \\
15^{\circ} 03.9^{\prime} \mathrm{E}\end{array}$ & 115 & 0.2 & $\begin{array}{c}0-3 \\
3-6 \\
7-10 \\
17-20 \\
27-30\end{array}$ & $\begin{array}{r}1.5 \\
4.5 \\
8.5 \\
18.5 \\
28.5\end{array}$ \\
\hline V & $\begin{array}{l}\text { Storfjord } \\
\text { (Svalbard) }\end{array}$ & $\begin{array}{l}77^{\circ} 33.0^{\prime} \mathrm{N} \\
19^{\circ} 05.5^{\prime} \mathrm{E}\end{array}$ & 175 & -1.7 & $\begin{array}{c}0-3 \\
3-6 \\
7-10 \\
17-20 \\
27-30\end{array}$ & $\begin{array}{r}1.5 \\
4.5 \\
8.5 \\
18.5 \\
28.5\end{array}$ \\
\hline
\end{tabular}

which could not be separated from the cells and masked them during microscopic investigations. Sonication was therefore not applied. Instead, subsamples were diluted with $0.2 \mu \mathrm{m}$ prefiltered seawater to a total volume of $5 \mathrm{ml}$ (a modification of Bak \& Nieuwland 1989 and van Duyl \& Kop 1990). At this dilution rate masking of bacterial cells was not a problem. The sample dilutions were stained with the fluorochrome DAPI (4',6-diamidino-2-phenylindole, $5 \mathrm{\mu g} \mathrm{ml}^{-1}$ final concentration; Schallenberg et al. 1989) for $10 \mathrm{~min}$ and subsequently concentrated on black polycarbonate membrane filters $(0.2 \mu \mathrm{m}$ pore size and $2.5 \mathrm{~cm}$ diameter). Filters were embedded with immersion oil on microscope slides and kept frozen until the organisms were counted. In order to avoid bottle effects such as the loss of cells due to fixation time (Turley \& Hughes 1994), all slides were prepared within 2 to 4 d of sampling. Prokaryotic cell counts were conducted with a Zeiss Axiophot epifluorescence microscope under UV light (Zeiss UV filter set No. 01: BP 365/12, FT 395, LP 397 ) at a magnification of $1250 \times$. At least 400 cells per filter were counted.

RNA extraction and slot-blot hybridization. For the molecular analyses, $2 \mathrm{ml}$ aliquots of sediment were frozen in liquid nitrogen immediately after sampling and stored at $-80^{\circ} \mathrm{C}$ until further use. Nucleic acids were isolated directly by bead-beating, phenol extraction and isopropanol precipitation, based on the methods described by Stahl et al. (1988) and MacGregor et al. (1997) with slight modifications. Sediment samples were resuspended in $\mathrm{NaPO}_{4}$-buffer (120 mM, pH 8) with $1 \%$ polyvinylpolypyrrolidone (PVPP; acid washed according to Holben et al. 1988) and the extraction was done with phenol-chloroform-isoamylalcohol equilibrated with TE-buffer ( $\mathrm{pH} 8$ ). After precipitation the nucleic acids were resuspended in DNase-buffer $(6 \mathrm{mM}$ $\mathrm{MgCl}_{2}, 40 \mathrm{mM}$ Tris- $\mathrm{HCl}, \mathrm{pH} 7.5$ ), treated with DNase for $30 \mathrm{~min}$, extracted, and precipitated with ethanol. IRNA was blotted on nylon membranes (Magna Charge, Micron Separations, Westborough, MA, USA) in triplicate and probed with radioactively labeled oligonucleotides (see below) as described previously (Stahl et al. 1988). Membranes were prehybridized at $40^{\circ} \mathrm{C}$ and washed at $44^{\circ} \mathrm{C}\left(\mathrm{S}-{ }^{-}-\right.$Univ-1390-a-A-18), $54^{\circ} \mathrm{C}$ (S-DBact-0338-a-A-18), or $56^{\circ} \mathrm{C}$ (S-D-Arch-0915-a-A-20). Intensity of hybridization signal was measured with a Phosphor Imager (Molecular Dynamics, Sunnyvale, CA, USA) and quantified according to an Escherichia coli rRNA standard (Boehringer, Mannheim, Germany). rRNA isolated from Methanolobus tindarius served as standard for hybridization with the archaeal probe. Calculations for prokaryotic rRNA were based on the sum of detected eubacterial and archaeal rRNA.

Oligonucleotide probes. Oligonucleotides were purchased from Biometra, Göttingen, Germany. The probes used were S-"-Univ-1390-a-A-18 (Stahl et al. 1988), which targets most known forms of life, S-D-Bact-0338-a-A-18 (Amann et al. 1990), which is specific for Bacteria, and S-D-Arch-0915-a-A-20 (Stahl \& Amann 1991) targeting Archaea. Names given here are according to Oligonucleotide Probe Database conventions (Alm et al. 1996). 


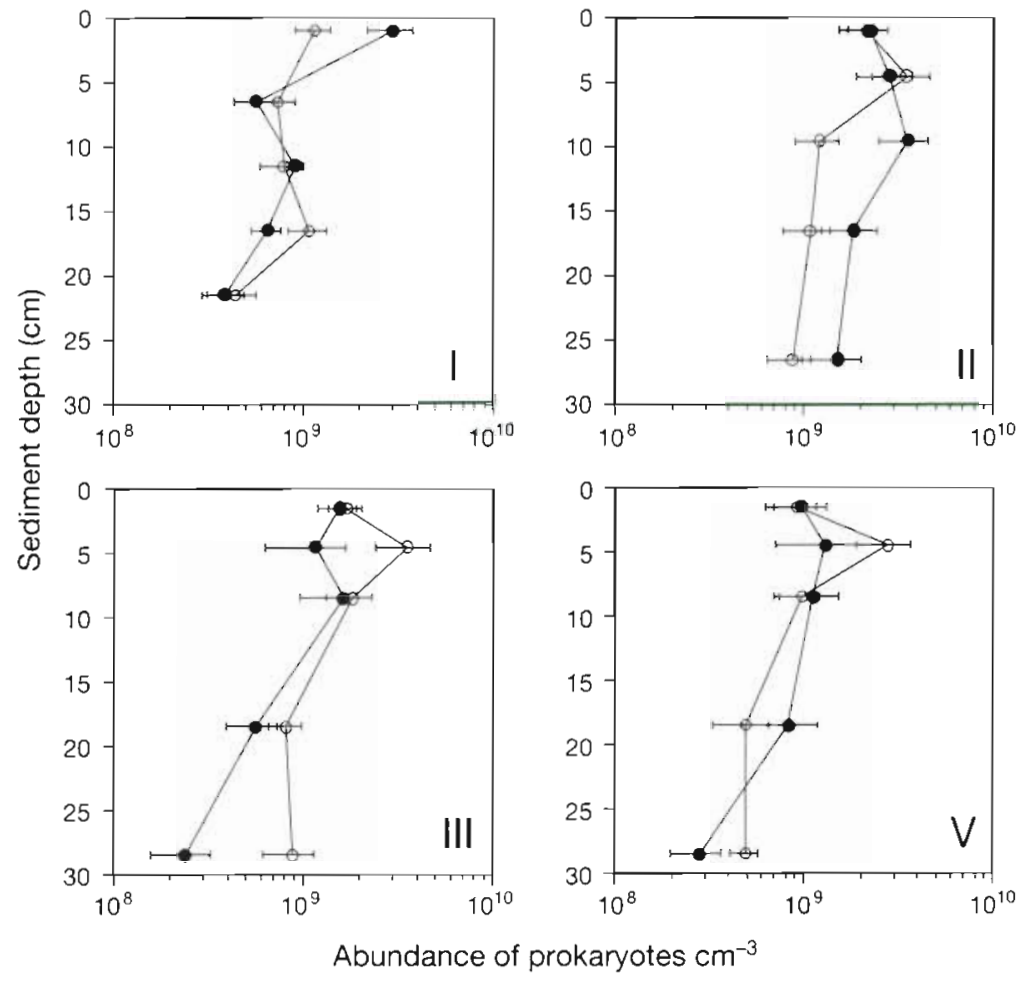

Fig. 1. Abundance of total benthic prokaryotes $\left(\mathrm{cm}^{-3}\right.$ of wet sediment) in different vertical sediment horizons from duplicate cores of 4 permanently cold stations (Stn I: Tromso, Stns II, III and V: Svalbard; see Table 1). Sediment depths refer to the mean depth of the respective sample. $(\bullet)$ Core $A_{i}$

(o) core B. Error bars indicate counting variability

\section{RESULTS \\ Bacterial abundances and vertical distribution}

Total prokaryotic abundances were in the range of ca $2 \times 10^{8}$ to $4 \times 10^{9}$ cells $\mathrm{cm}^{-3}$ of wet sediment (Fig. 1) and did not differ

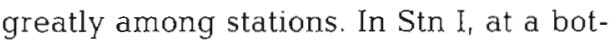
tom water temperature of $7^{\circ} \mathrm{C}$, the warmest site, prokaryotic cell numbers peaked at the sediment surface $\left(3 \times 10^{9}\right.$ and $1.2 \times 10^{9}$ cells $\mathrm{cm}^{-3}$ in the parallel cores $\mathrm{A}$ and $\mathrm{B}$, respectively) and generally decreased with increasing sediment depth. In contrast, in all sediments collected from the colder Svalbard region, with the exception of one core, prokaryotic cell numbers reached medium values at the sediment surface $\left(9.2 \times 10^{8}\right.$ to $2.3 \times$ $10^{9}$ cells $\left.\mathrm{cm}^{-3}\right)$, showed a slight subsurface peak at 5 to $10 \mathrm{~cm}$ depth $\left(1.2 \times 10^{9}\right.$ to $3.5 \times 10^{9}$ cells $\mathrm{cm}^{-3}$ ) and were lowest in the deepest sediment horizons investigated (20 to $30 \mathrm{~cm}$ depth; $2.4 \times 10^{8}$ to $1.5 \times$ $10^{9}$ cells $\mathrm{cm}^{-3}$ ).
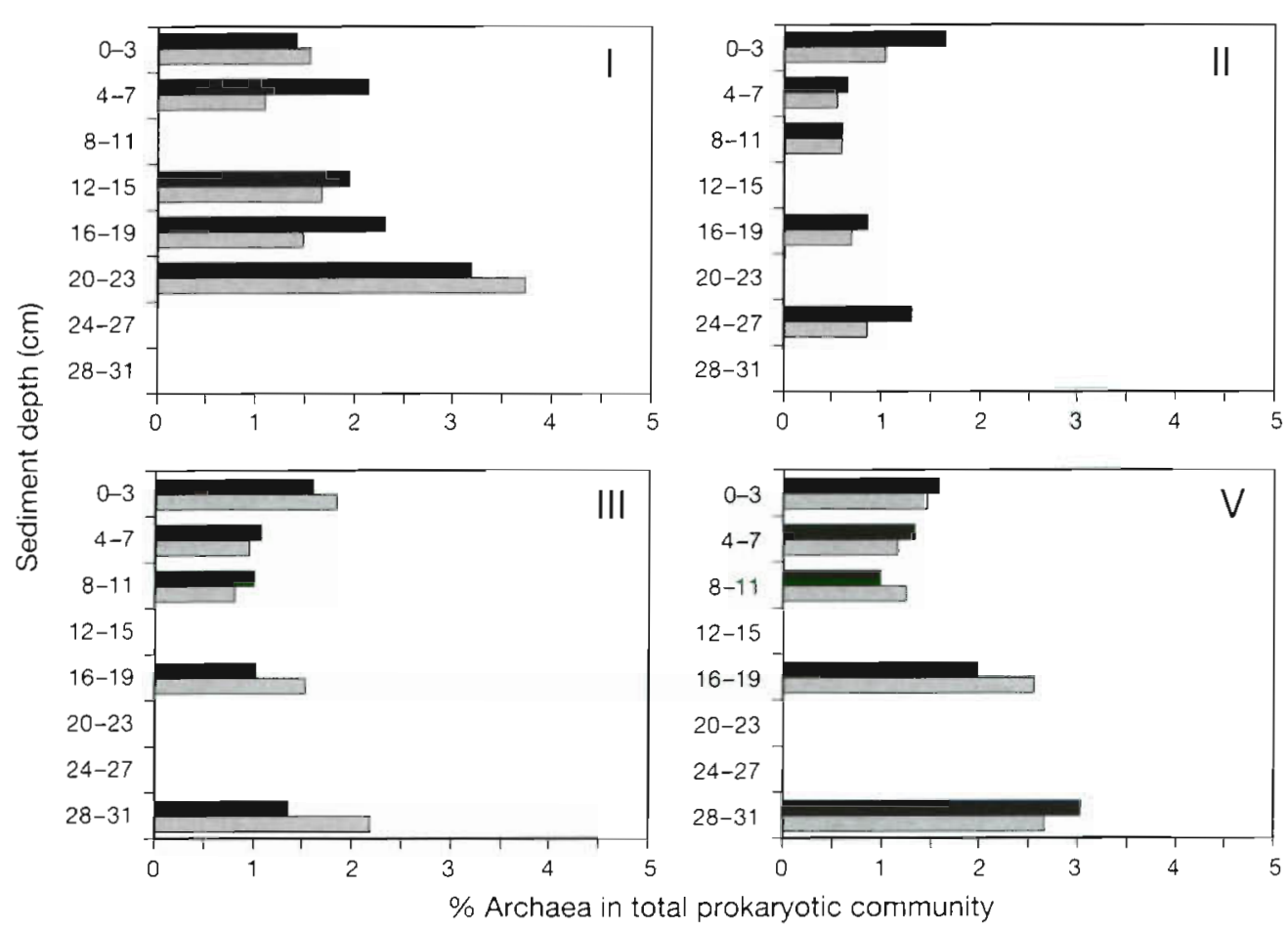

Fig. 2. Relative abundance of Archaea in the total prokaryotic community (as determined by rRNA hybridization) in different vertical sediment horizons from duplicate cores of 4 permanently cold stations. The respective mean depths of the samples fall within the ranges given on the $y$-axis. Black bars: core $A_{i}$ grey bars . core B 


\section{Bacterial community structure}

Slot-blot hybridization allowed differentiation between Archaea and Bacteria, and the calculation of their relative contributions to the total prokaryotic community. All stations and all sediment depths were clearly dominated by Bacteria, making up at least $96 \%$ of the prokaryotic rRNA (Fig. 2). The relative contribution of Archaea was different at Stn I to that at the 3 Svalbard stations (Strs II, III, and V). At Stn I the percentage of Archaea was increasing with depth (1.2 to $3.9 \%)$. At the 3 Svalbard stations, Archaea had a peak at the surface (around $1.5 \%$ ) decreased to $0.6-1 \%$ at a depth of $11 \mathrm{~cm}$ and increased again below $15 \mathrm{~cm}$ depth to a maximum of 1.4-3\%. Absolute recovery of archaeal rRNA was highest near the sediment surface, with up to $250 \mathrm{ng}$ archaeal rRNA $\mathrm{cm}^{-3}$ sediment. Recovery decreased rapidly with increasing sediment depth and was in the range of $<10$ to

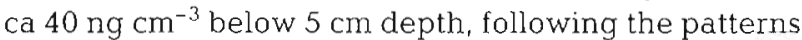
observed for the distribution of total prokaryotic IRNA. vertical distribution (Fig. 3). At all stations, concentrations were highest directly at the sediment surface and decreased with sediment depth. The highest concentrations were measured at Stn II, where they exceeded the values of all other stations at each depth (numbers are for the parallel cores A and B, respectively): 15.4 and $24.4 \mu \mathrm{g}$ bacterial $\mathrm{rRNA} \mathrm{cm}^{-3}$ at the sediment surface and 0.7 and $1.1 \mu \mathrm{grRNA} \mathrm{cm}^{-3}$ in the deepest investigated horizon, at $26.5 \mathrm{~cm}$ depth. The other stations differed mainly in the total rRNA concentrations at the sediment surface (4.2 and 4.1,9.5 and 5.2, and 10.7 and $11.3 \mu \mathrm{g}$ rRNA $\mathrm{cm}^{-3}$ in the 2 parallel cores $A$ and B from Stns I, V and III, respectively). Values decreased sharply underneath the sediment surface, and below ca $5 \mathrm{~cm}$ depth the vertical differences and the differences between the stations I, III and IV became smaller (ranges for differences in maximum and minimum values between stations from $2-1.3$ to $0.08-0.3 \mu \mathrm{g} \mathrm{rRNA} \mathrm{cm}^{-3}$ ).

\section{Total rRNA concentrations}

The total prokaryotic rRNA, determined as the sum of the eubacterial and archaeal signals, showed a clear

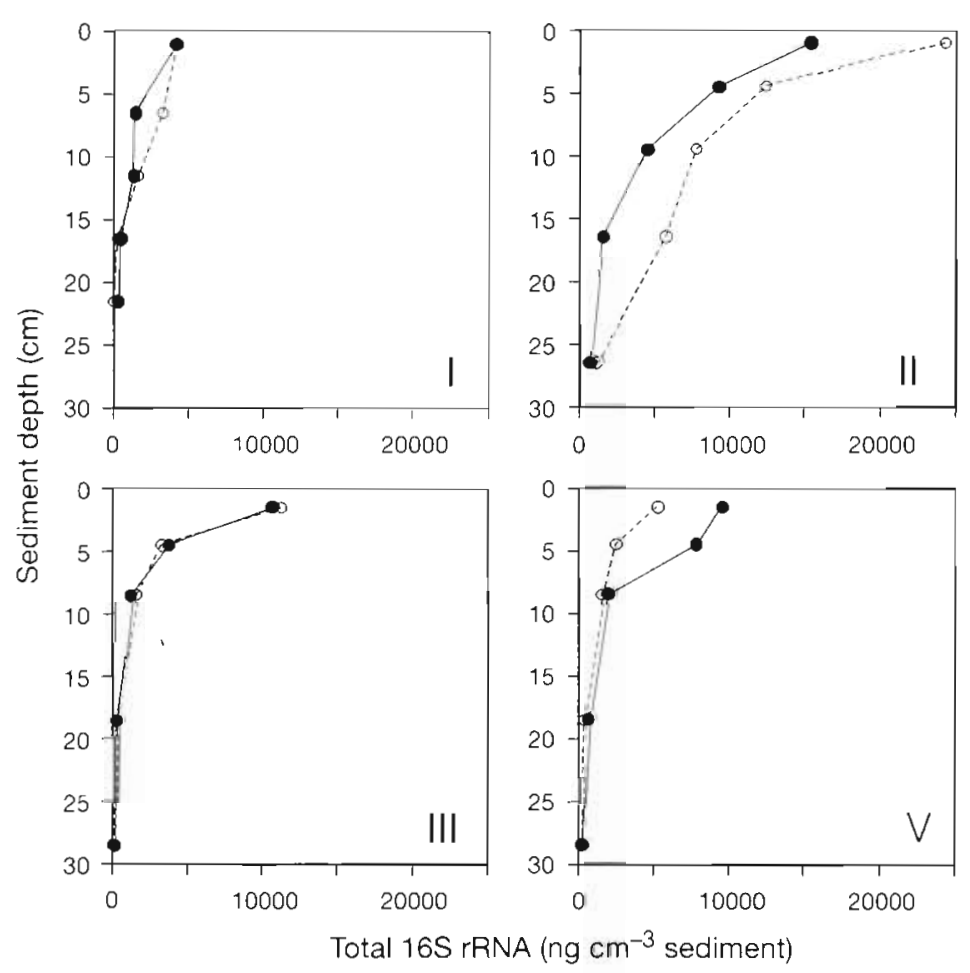

Fig. 3. Total prokaryotic rRNA recovery determined by slot-blot hybridization in different vertical sediment horizons from duplicate cores of 4 permanently cold stations. Sediment depths refer to the mean depth of the respective sample.

\section{Cellular rRNA contents}

For each sediment sample processed, our analysis included the enumeration of total bacterial abundance and the quantification of total prokaryotic rRNA, i.e. the sum of eubacterial and archaeal rRNA. This combination allowed the calculation of rRNA content per prokaryotic cell in each sample (Fig. 4, Table 2). In samples from the 3 Svalbard stations (II, III, and V), a clear vertical pattern was seen. Maximum values were found in the surface samples (ca 7 to 9 fg rRNA cell-1) and decreased with increasing sediment depth. At Stns III and $V$, this decrease was most pronounced, percell content of rRNA was less than $2 \mathrm{fg}$ below a sediment depth of $5 \mathrm{~cm}$. At Stn II, the decrease was more gradual and a value $<2$ fg rRNA cell ${ }^{-1}$ was only recorded in the deepest horizon $(26.5 \mathrm{~cm})$. At the mainland station (Stn I), the maximum rRNA content per prokaryotic cell was found in a subsurface sediment layer at $6.5 \mathrm{~cm}$ depth $(4 \mathrm{fg}$ rRNA cell ${ }^{-1}$ ); at all other depths, including the sediment surface, each prokaryote contained on average $2 \mathrm{fg}$ rRNA or less. The mean rRNA content of the cells (averaging all samples) was close to $3 \mathrm{fg}$ rRNA cell ${ }^{-1}$

We also investigated the correlation between abundance of prokaryotes and the total concentration of prokaryotic IRNA in the individual samples (Table 3). When combining the duplicate cores from all stations and all vertical sediment sections ( $\mathrm{n}=$ 


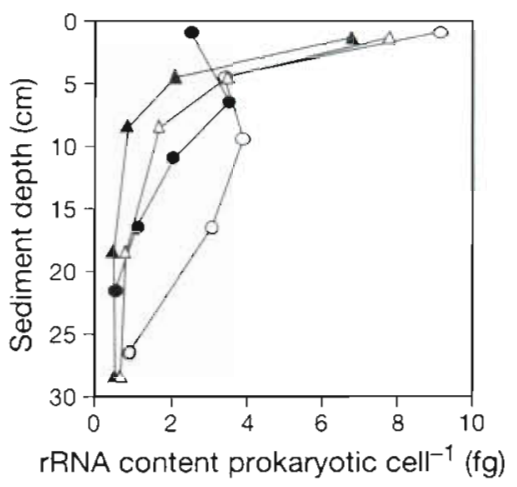

Fig. 4. Calculated rRNA contents per prokaryotic cell (see text for further details) in different vertical sediment horizons of 4 permanently cold stations. Sediment depths refer to the mean depth of the respective sample. Values are means of

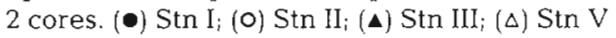

40 ), we could not detect a statistical significance for such a correlation $\left(\mathrm{r}^{2}=0.222\right)$. However, when we differentiated 2 distinct vertical horizons within the sediment column (from the sediment surface down to ca $5.5 \mathrm{~cm}$ and below ca $5.5 \mathrm{~cm}$ depth), we obtained a different result. There was still no statistically significant correlation between prokaryotic cell numbers and rRNA concentration in the upper sediment layer $\left(\mathrm{r}^{2}=\right.$ 0.007 ), but the 2 parameters were strongly positively correlated in the deeper sediment samples $\left(\mathrm{r}^{2}=0.739\right)$. This correlation was even stronger when the data sets for only the 3 Svalbard stations were considered $\left(\mathrm{r}^{2}=\right.$ $0.821)$

\section{DISCUSSION}

\section{Bacterial abundance}

The limited available literature data for microbial processes in cold environments suggest that the rates of degradation of organic matter are comparable to those of temperate regions (Nedwell et al. 1993, Arnosti et al. 1998, Sagemann et al. 1998). In contrast to this, there is some indication from laboratory and field studies that the activity of bacteria decreases with decreasing temperatures (Mayer 1989, van Duyl \& Kop 1990). One explanation for this discrepancy could be that prokaryotic cell numbers in cold environments may be higher than those of temperate regions, resulting in a higher overall turnover rate. The results of the enumeration of total prokaryotes in sediment samples collected in our arctic study sites
Table 3. Correlation between bacterial numbers and rRNA content in different vertical horizons of sediment samples from 4 permanently cold stations

\begin{tabular}{|lcc|}
\hline Stns & Depth range $(\mathrm{cm})$ & Correlation coefficient \\
\hline I, II, III, V & $0-5.5$ & 0.007 \\
I, II, III, V & $5.5-28.5$ & 0.739 \\
II, III, V & $0-5.5$ & 0.032 \\
II, III, V & $5.5-28.5$ & 0.821 \\
\hline
\end{tabular}

could not confirm this hypothesis (Fig. 1). The abundances and vertical distribution of prokaryotes we found in our sediment samples were comparable to results obtained from a large variety of temperate marine and freshwater sediments (van Duyl \& Kop 1990, Parkes et al. 1994, Epstein \& Rossel 1995, Hondeveld et al. 1995, Starink 1995, Gieseke 1997). Given the relatively high absolute rates of organic matter degradation suggested for our systems (Nedwell et al. 1993. Arnosti et al. 1998, Sagemann et al. 1998) this implies that per cell prokaryotic activity cannot be lower in the cold temperature environments. As opposed to obtaining only prokaryotic cell numbers, the calculation of cellular rRNA contents may serve as an indicator for prokaryotic activity.

\section{Cellular rRNA contents as compared to metabolic activity at different stations}

One of the earliest fundamental observations in microbial physiology was the detection of a correlation between cellular ribosome (rRNA) content and growth rate of bacteria (Schaechter et al. 1958). However, there seems to be no universal relationship between prokaryotic activity and rRNA content. Kemp et al. (1993) investigated 4 marine bacterial isolates and found no common conversion factor between rRNA contents and growth rate, although each individual isolate showed a close coupling between the 2 parameters. Furthermore, Jeffrey et al. (1996) found no sig-

Table 2. rRNA content per bacterial cell from 4 permanently cold stations (median of 10 sediment samples)

\begin{tabular}{|lccc|}
\hline Stn no. & $\begin{array}{c}\text { Bottom water } \\
\text { temperature }\left({ }^{\circ} \mathrm{C}\right)\end{array}$ & $\begin{array}{c}\text { Average } \\
\text { rRNA cell }{ }^{-1}\left(\mathrm{fg} \text { cell }^{-1}\right)\end{array}$ & $\begin{array}{c}\text { Approx. no. of } \\
\text { ribosomes cell }\end{array}$ \\
\hline I & 7.0 & 1.5 & 580 \\
II & 2.6 & 3.4 & 1300 \\
III & 0.2 & 0.9 & 350 \\
V & -1.7 & 1.3 & 500 \\
a Based on 16S and 23S rRNA with an average size of 4500 bases, a ribo- \\
some has an approximate mass of $2.6 \times 10^{-3} \mathrm{fg}$
\end{tabular}


nificant relationship between RNA:DNA ratios and either $\left[{ }^{3} \mathrm{H}\right]$-thymidine or $\left[{ }^{14} \mathrm{C}\right]$-leucine incorporation for marine picoplankton. This implies that due to the low metabolic activity and the heterogeneity of the natural prokaryotic community it may be difficult to use these general parameters as indicators for the whole prokaryotic community. Bearing these limitations in mind, we calculated the average amount of rRNA per cell by dividing the sum of total prokaryotic rRNA by the number of DAPI-stained cells (Fig. 4). Based on the simplified assumption that all prokaryotes in our sediment samples had the same amount of rRNA, our calculations yielded a range for IRNA content per cell for the 3 Svalbard stations of $<2$ to $9 \mathrm{fg} \mathrm{cell}^{-1}$ or an average of approximately 1000 ribosomes. These numbers fall well within those determined for planktonic bacteria from temperate environments by Jeffrey et al. (1996) $\left(9.44 \pm 6.25 \mathrm{fg} \mathrm{cell}^{-1}\right)$ and Lee \& Kemp (1994) (1.6 to $\left.5.4 \mathrm{fg} \mathrm{cell}^{-1}\right)$.

Cellular rRNA concentrations have also been studied with pure cultures. When investigating a culture of Desulfovibrio sp. in a chemostat under conditions of slow growth ( $35 \mathrm{~h}$ generation time), Poulsen et al. (1993) found a per cell rRNA content of $30 \mathrm{fg}$. This is approximately 10 times higher than the amount calculated for our sediment samples. However, the same species had a significantly lower rRNA content in an established biofilm, as could be seen by a significantly lower fluorescence intensity during in situ hybridization. This shows that cellular rRNA in a multispecies community can be considerably lower than in slowly growing pure cultures.

A further question in our study was whether cellular rRNA contents may be related to in situ activity. The highest rRNA content per cell among our sites was found at Stn II, which had the warmest bottom water temperature $\left(2.6^{\circ} \mathrm{C}\right)$ among the stations from Svalbard. Rates of polysaccharide hydrolysis and oxygen consumption (Arnosti et al. 1998), nitrate reduction (B. Thamdrup pers. comm.) and sulfate reduction (Sagemann et al. 1998), measured at in situ temperature during the same cruise as that of our study, were all highest at this station. This suggests that the average rRNA content per cell reflects the activity of the whole prokaryotic community and might serve as an indicator for prokaryotic activity, at least when habitats of similar temperature range and local proximity are compared. The same conclusions can be drawn when comparing per cell rRNA contents and sulfate reduction rates measured in parallel samples from a single vertical profile. Sagemann et al. (1998) described low (sulfate reduction) rates below a depth of 15 to $20 \mathrm{~cm}$ for all stations, which coincides with the depth where, based on our calculations, the rRNA content per cell reached the minimum at all stations.

\section{Vertical rRNA profiles}

While Jeffrey et al. (1996) reported a positive correlation between prokaryotic abundance and total prokaryotic rRNA concentration in all their samples, we could only confirm this for sediment layers below $5.5 \mathrm{~cm}$ for the Svalbard stations and for depths below $6.5 \mathrm{~cm}$ for Stn I (Table 3). In the top layers of the sediments investigated we found a large variety of rRNA contents for individual bacteria, including very high values of almost $10 \mathrm{fg} \mathrm{cell}^{-1}$ down to a minimum of $2 \mathrm{fg}$ cell $^{-1}$. This lack of correlation in the sediment surface has also been found in sediment samples from the Baltic Sea off the Danish coast (K. Sahm, B. J. MacGregor \& D. A. Stahl unpubl. data). It implies that different factors may be involved in the regulation of prokaryotic rRNA content in the upper layers of the sediment compared to deeper horizons. The missing correlation between cell number and recovered rRNA could reflect a more complex prokaryotic population closer to the sediment surface, consisting of different species with different rRNA contents due to speciesspecific properties, different cell sizes, different metabolic activity states, or a combination of all. These questions are difficult to address with the cell-disruptive method employed in our study. For future investigations, in situ hybridization with specific fluorescently labeled rRNA-targeted oligonucleotide probes promises to be an appropriate method to study speciesspecific differences within complex microbial communities, but it still has to be optimized for use in sediments

A further reason for the missing correlation of recovered rRNA and prokaryotic cell number near the sediment surface could lie within trophic interactions. In contrast to pelagic systems, little is known so far on the relative importance of nutrient supply and grazing pressure from benthic protozoa and meiobenthos as control factors for the abundance and activity of benthic prokaryotes (Wright 1988, Epstein \& Shiaris 1992, Berninger \& Epstein 1995, Hondeveld et al. 1995, Starink et al. 1996). Grazing pressure may be higher in the top ca $5.5 \mathrm{~cm}$ of the sediment, where Pfannkuche \& Thiel (1987), when investigating sediment samples from different stations on the northeast-Svalbard shelf and in the arctic Nansen Basin, found 95\% of the meiobenthos to be present. Differences in nutrient availability, degradability of organic matter, and grazing pressure compared to deeper sediment layers could explain the higher prokaryotic rRNA content and its larger variation in the sediment surface samples. It remains to be determined how far recovery of rRNA due to differences in sediment matrix and in cell lysis efficiency gives a bias to our results. We regard the comparability of the results from stations with obvi- 
ously difference sediment types as an indication that this bias is of negligible importance.

In summary, our results show that the depth profile of the rRNA content per cell indicates 3 zones in the sediment profile. The first zone is the upper 5 to $6 \mathrm{~cm}$, where we see no correlation between prokaryotic abundance and rRNA recovery, possibly reflecting complex interactions between the procaryotes and a diverse population of micro-, meio- and macroorganisms. This is followed by a second zone of decreasing cellular rRNA content at a depth of ca 5.5 to $9 \mathrm{~cm}$ (Stn III) or ca 5.5 to $17 \mathrm{~cm}$ (all other stations). Here, prokaryotic activity, for example in the form of sulfate reduction, is measurable but nutrient supply is likely lower and interactions with meiobenthos might be less important. The third zone is below $15 \mathrm{~cm}$ depth. It is a zone where sulfate reduction as well as rRNA concentration per cell are low, possibly indicating a dormant prokaryotic population.

\section{Archaea in permanently cold sediments}

In recent molecular studies it has been recognized that Archaea, long thought to be restricted to extreme environments, are common and widespread in nonthermophilic marine and freshwater habitats (DeLong et al. 1994, Fuhrman \& Davis 1997, MarGregor et al. 1997. Massana et al. 1997). Newly identified types of Archaea play a significant role in the marine picoplankton community with archaeal rRNA accounting for more than $20 \%$ of the total prokaryotic IRNA in a temperate coastal habitat and for up to $34 \%$ in coastal antarctic surface water (DeLong et al. 1994, Massana et al. 1997). As representatives of these newly found types are as yet uncultured, their role in the ecosystem is unknown. In contrast to the published results from the pelagic zone, Archaea never exceeded $4 \%$ of the total prokaryotic community in our sediment samples. Our results compare well with results from freshwater sediments, where archaeal rRNA amounted to approximately $1 \%$ of the total prokaryotic rRNA (B. MacGregor pers. comm.), and to results from sediment samples taken from the Baltic Sea, where Archaea contributed between 1 and $12 \%$ of the total prokaryotic rRNA (Sahm et al. unpubl. data). MacGregor et al. (1997) discussed specific recovery problems for archaeal rRNA due to inefficient cell lysis. Differences in the sediment matrix along the depth profile may also affect recovery rates of rRNA. It remains to be determined whether this gives a strong bias for sediment samples in particular, before we can draw final conclusions on the relatively small contribution of Archaea to the total prokaryotic community in the examined samples. The current results indicate that Archaea play only a minor role in benthic environments and that there is no significant difference in the occurrence of Archaea between permanently cold and temperate habitats.

In conclusion, our investigation of the prokaryotic community of permanently cold arctic sediments yielded less differences to results obtained from temperate regions than we had expected based on existing data sets. This implies that factors other than temperature may be more important in regulating prokaryotic abundances, growth rates and communiy composition in these systems. While this is surprising in view of findings from laboratory cultures, it is consistent with other field studies (Rivkin et al. 1996). Furthermore, we demonstrated that the simplified approach of calculating cellular rRNA on the basis of rRNA slot-blot hybridization and total cell counts could indicate general prokaryotic activity in a certain habitat and for different activity zones in our sediment samples.

Acknowledgements. We are grateful to Donna Jovin for the opportunity to use the Phosphor Imager in her laboratory, to Jens Harder for supplying pure Archaea cultures for the isolation of reference rRNA, to Don Canfield for his excellent work as cruise leader, and to the captain and crew of RV 'Jan Mayen' for all their help on the cruise. We thank Rudolf Amann, Barbara MacGregor and 4 anonymous reviewers for their valuable comments on our manuscript.

\section{LITERATURE CITED}

Albright LJ, MCCrae SK (1987) Annual bacterioplankton biomasses and productivities in a temperate west coast Canadian fjord. Appl Environ Microbiol 53:1277-1285

Alm EW, Oerther DB, Larsen N, Stahl DA, Raskin L (1996) The oligonucleotide probe database. Appl Environ Microbiol 62:3557-3559

Amann RI, Krumholz L, Stahl DA (1990) Fluorescent-oligonucleotide probing of whole cells for determinative, phylogenetic, and environmental studies in microbiology. J Bacteriol 172:762-770

Amann RI, Ludwig W, Schleifer KH (1995) Phylogenetic identification and in situ detection of individual microbial cells without cultivation. Microbiol Rev 59:143-169

Arnosti C, Jorgensen BB, Sagemann J, Thamdrup B (1998) Temperature dependence of microbial degradation of organic matter in manine sediments: polysaccharide hydrolysis, oxygen consumption, and sulfate reduction. Mar Ecol Prog Ser 165:59-70

Bak RPM, Nieuwland G (1989) Seasonal fluctuations in benthic protozoan populations at different depths in marine sediments. Neth J Sea Res 24:37-44

Berninger UG, Epstein SS (1995) Vertical distribution of benthic ciliates in response to the oxygen concentration in an intertidal North Sea sediment. Aquat Microb Ecol 9:229-236

Berninger UG, Finlay BJ, Kuuppo-Leinikki P (1991) Protozoan control of bacterial abundances in freshwater. Limnol Oceanogr 36:139-147

Boetius A, Lochte K (1996) Effect of organic enrichments on hydrolytic potentials and growth of bacteria in deep-sea sediments. Mar Ecol Prog Ser 140:239-250 
Caron DA, Davis PG, Madin LP, Sieburth JM (1982) Heterotrophic bacteria and bacterivorous protozoa in oceanic macroaggregates. Science 218:795-797

Cole JJ, Findlay S, Pace ML (1988) Bacterial production in fresh and saltwater ecosystems: a cross-system overview. Mar Ecol Prog Ser 43:1-10

DeLong EF, Wu KY, Prézelin BB, Jovine RVM (1994) High abundance of Archaea in antarctic marine picoplankton. Nature 371:695-697

Devereux R, Winfrey MR, Winfrey J, Stahl DA (1996) Depth profile of sulfate-reducing bacterial ribosomal RNA and mercury methylation in an estuarine sediment. FEMS Microbiol Ecol 20:23-31

Epstein SS, Rossel J (1995) Enumeration of sandy sediment bacteria: search for optimal protocol. Mar Ecol Prog Ser $117: 289-298$

Epstein SS, Shiaris MP (1992) Rates of microbenthic and meiobenthic bacterivory in a temperate muddy tidal-flat community. Appl Environ Microbiol 58:2426-2431

Fenchel T, Finlay BJ (1995) Ecology and evolution in the anoxic world. Oxford University Press, Oxford

Fuhrman JA, Davis AA (1997) Widespread Archaea and novel Bacteria from the deep sea as shown by $16 \mathrm{~S}$ rRNA gene sequences. Mar Ecol Prog Ser 150:275-285

Gieseke A (1997) Benthische Ciliaten, ihre Verteilung und ihre Rolle im Nahrungsgefüge des Wattenmeersediments der Nordsee. Institute of Zoology, Hannover School of Veterinary Medicine, Hannover

Holben WE, Jansson JK, Chelm BK, Tiedje JM (1988) DNA probe method for the detection of specific microorganisms in the soil bacterial community. Appl Environ Microbiol $54: 703-711$

Hondeveld BJM, Nieuwland G, van Duyl FC, Bak RPM (1995) Impact of nanoflagellate bacterivory on benthic bacterial production in the North Sea. Neth J Sea Res 34:275-287

Jeffrey WH, Von Haven R, Hoch MP, Coffin RB (1996) Bacterioplankton RNA, DNA, protein content and relationship to rates of thymidine and leucine incorporation. Aquat Microb Ecol 10:87-95

Jørgensen BB (1982) Mineralization of organic matter in the sea bed-the role of sulphate reduction. Nature 296: $643-645$

Kemp PF, Lee S, LaRoche J (1993) Estimating the growth rate of slowly growing marine bacteria from RNA content. Appl Environ Microbiol 59:2594-2601

Kröncke I, Tan TL, Stein R (1994) High benthic bacteria standing stock in deep arctic basins. Polar Biol 14:423-428

Lee S, Kemp PF (1994) Single-cell RNA content of natural marine planktonic bacteria measured by hybridization with multiple $16 \mathrm{~S}$ rRNA-targeted fluorescent probes. Limnol Oceanogr 39:869-879

Lochte K (1992) Bacterial standing stock and consumption of organic carbon in the benthic boundary layer of the abyssal North Atlantic. In: Rowe GT, Pariente V (eds) Deep sea food chains and the global carbon cycle. Kluwer Academic Publishers, Dordrecht, p 1-10

Lochte K, Turley CM (1988) Bacteria and cyanobacteria associated with phytodetritus in the deep sea. Nature 333:67-69

MacGregor BJ, Moser DP, Wheeler Alm E, Nealson KH, Stahl DA (1997) Crenarchaeota in Lake Michigan sediment. Appl Environ Microbiol 63:1178-1181

Massana R, Murray AE, Preston CM, DeLong EF (1997) Vertical distribution and phylogenetic characterization of marine planktonic Archaea in the Santa Barbara Channel. Appl Environ Microbiol 63:50-56

Mayer LM (1989) Extracellular proteolytic enzyme activity in sediments of an intertidal mudflat. Limnol Oceanogr 34 :
$973-981$

Meyer-Reil L.A, Köster M (1992) Microbial life in pelagic sediment: the impact of environmental parameters on enzymatic degradation of organic material. Mar Ecol Prog Ser $81: 65-72$

Morita RY (1975) Psychrophilic bacteria. Bacteriol Rev 39 $144-167$

Nedwell DB, Walker TR, Ellis-Evans JC, Clarke A (1993) Measurements of seasonal rates and annual budgets of organic carbon fluxes in an antarctic coastal environment at Signy Island, South Orkney Islands, suggest a broad balance between production and decomposition. Appl Environ Microbiol 59:3989-3995

Parkes RJ, Cragg BA, Bale SJ, Getliff JM, Goodman K, Rochelle PA, Fry JC, Weightman AJ, Harvey SM (1994) Deep bacterial biosphere in Pacific Ocean sediments. Nature 371:410-413

Pfannkuche O. Thiel H (1987) Meiobenthic stocks and benthic activity on the NE-Svalbard shelf and in the Nansen Basin. Polar Biol 7:253-266

Poulsen LK, Ballard G, Stahl DA (1993) Use of rRNA fluorescence in situ hybridization for measuring the activity of single cells in young and established biofilms. Appl Environ Microbiol 59:1354-1360

Rivkin RB, Anderson MR, Lajzerowicz C (1996) Microbial processes in cold oceans. I. Relationship between temperature and bacterial growth rate. Aquat Microb Ecol 10:243-254

Russel NJ (1990) Cold adaptation of microorganisms. Phil Trans R Soc Lond Ser B 326:595-611

Sagemann J, Jorgensen BB, Greeff O (1998) Temperature dependence and rates of sulfate reduction in cold sediments of Svalbard, Arctic Ocean. Geomicrobiol J (in press)

Sanders RW, Caron DA, Berninger UG (1992) Relationships between bacteria and heterotrophic nanoplankton in marine and fresh waters: an inter-ecosystem comparison. Mar Ecol Prog Ser 86:1-14

Schaechter M, Maaloe O, Kjeldgaard NO (1958) Dependency on medium and temperature of cell size and chemical composition during balanced growth of Salmonella typhimurium. J Gen Microbiol 19:592-606

Schallenberg M, Kalff J, Rasmussen JB (1989) Solutions to problems in enumerating sediment bacteria by direct counts. Appl Environ Microbiol 55:1214-1219

Stahl DA, Amann RI (1991) Development and application of nucleic acid probes in bacterial systematics. In: Stackebrandt E, Goodfellow M (eds) Nucleic acid techniques in bacterial systematics. John Wiley \& Sons Ltd, Chichester, p 205-248

Stahl DA, Flesher B, Mansfield HR, Montgomery L (1988) Use of phylogenetically based hybridization probes for studies of ruminal microbial ecology. Appl Environ Microbiol 54: 1079-1084

Starink M (1995) Seasonal variation in bacterial production, protozoan grazing, and abundances in sediments of a freshwater littoral zone. Faculty of Biology, University of Amsterdam

Starink M, Bär-Gilissen MJ, Bak RPM, Cappenberg TE (1996) Bacterivory by heterotrophic nanoflagellates and bacterial production in sediments of a freshwater littoral system. Limnol Oceanogr 41:62-69

Teske A, Wawer C, Muyzer G, Ramsing NB (1996) Distribution of sulfate reducing bacteria in a stratified Fjord (Mariager Fjord, Denmark) as evaluated by most-probable-number counts and denaturing gradient gel electrophoresis of PCR-amplified ribosomal DNA fragments. Appl Environ Microbiol 62:1405-1415 
Turley CM, Hughes DJ (1994) The effect of storage temperature on the enumeration of epifluorscence-detectable bacterial cells in preserved sea-water samples. J Mar Biol Assoc UK 74:259-262

van Duyl FC, Kop AJ (1990) Seasonal patterns of bacterial production and biomass in intertidal sediments of the western Dutch Wadden Sea. Mar Ecol Prog Ser 59:249-261

van Duyl FC, van Raaphorst W, Kop AJ (1993) Benthic bacterial production and nutrient sediment-water exchange in sandy North Sea sediments. Mar Ecol Prog Ser 100:85-95

Editorial responsibility: Otto Kinne (Editor), Oldendorf/Luhe, Germany
Wellsbury P, Herbert RA, Parkes RJ (1993) Incorporation of [methyl- ${ }^{3} \mathrm{H}$ ]thymidine by obligate and facultative anaerobic bacteria when grown under defined culture conditions. FEMS Microbiol Ecol 12:87-95

Wellsbury P, Herbert RA, Parkes RJ (1996) Bacterial activity and production in near-surface estuarine and freshwater sediments. FEMS Microb Ecol 19:203-214

Wright RT (1988) A model for short-term control of the bacterioplankton by substrate and grazing. Hydrobiologia 159:111-117

Submitted: October 6, 1997; Accepted: February 11, 1998

Proofs received from author(s): April 2, 1998 